\title{
CONSERVATION
}

\section{Review of thirty-two years of toothed whale strandings in Santa Catarina, southern Brazil (Cetacea: Odontoceti)}

\author{
Thaís dos S. Vianna ${ }^{1 *}$, Carolina Loch ${ }^{1,2}$, Pedro V. de Castilho ${ }^{3}$, Morgana C. Gaidzinski ${ }^{4}$ \\ Marta J. Cremer ${ }^{5} \&$ Paulo C. Simões-Lopes ${ }^{1}$
}

\begin{abstract}
${ }^{1}$ Laboratório de Mamíferos Aquáticos, Departamento de Ecologia e Zoologia, CCB, Universidade Federal de Santa Catarina. 88040-960 Florianópolis, SC, Brazil.

2 Sir John Walsh Research Institute, Faculty of Dentistry, University of Otago. Dunedin 9054, New Zealand.

${ }^{3}$ Departamento de Engenharia de Pesca, Universidade do Estado de Santa Catarina. 88790-000 Laguna, SC, Brazil.

${ }^{4}$ Museu de Zoologia Professora Morgana Cirimbelli Gaidzinski, Universidade do Extremo Sul Catarinense. 88806-000 Criciúma, SC, Brazil.

${ }^{5}$ Laboratório de Nectologia, Departamento de Ciências Biológicas, Universidade da Região de Joinville. 89240-000 São Francisco do Sul, SC, Brazil.

*Corresponding author. E-mail: viannasthais@gmail.com
\end{abstract}

\begin{abstract}
Marine mammal strandings provide valuable insights into local biodiversity. Strandings can be caused by both natural and anthropogenic factors. In the state of Santa Catarina, Southern Brazil, organized marine mammal collections started in the 1980s through opportunistic and non-systematic collection efforts, representing a record of over 30 years of marine biodiversity. This study aimed to perform a preliminary review of 32 years of stranding records within this region. The secondary aim was to elucidate the stranding dynamics of the three most commonly recorded species. A total of 460 records were obtained, representing 17 species of odontocetes. The species registered most frequently were the franciscana, Pontoporia blainvillei (Gervais \& d' Orbigny, 1844) $(n=173)$, bottlenose dolphin, Tursiops truncatus (Montagu, 1821) $(n=100)$, and Guiana dolphin Sotalia guianensis (Van Bénéden, 1864) $(n=97)$. Most of the stranding records were observed in the second half of the year during the austral winter and spring. The apparent causes of death could not be determined for most of the specimens due to carcass decomposition. For the specimens in which the apparent cause of death could be determined, $27 \%$ of the strandings were compatible with anthropogenic interactions. While the focus of this study was a preliminary assessment of stranding data obtained through opportunistic collection, it is evident that future systematic monitoring efforts and stable networks of collaborators will generate more reliable coastal biodiversity inventories and will allow the knowledge of population dynamics of marine mammal species. In particular, for threatened and vulnerable species, or species with poor natural history data, strandings are a fundamental tool for the understanding of marine biodiversity. Ideally, future more refined analyses of stranding data should be used to inform conservation and management policies and to elucidate the biology and ecology of marine and coastal ecosystems within this region.
\end{abstract}

KEY WORDS. Bycatch, marine mammals, Pontoporia blainvillei, Sotalia guianensis, Tursiops truncatus.

Marine mammal strandings provide valuable records of biodiversity in coastal areas worldwide (MACLEOD et al. 2005, LEENEY et al. 2008, Pyenson 2010). Deceased-stranded specimens offer fundamental anatomical and morphological data that otherwise would not be available due to the logistic and financial limitations of studying cetaceans in their living marine habitats (Pyenson 2010). Strandings can be caused by both natural and anthropogenic factors. Agents such as biotoxins, contaminants, parasites, diseases, environmental factors and interactions with fisheries are commonly associated with marine mammal strandings (GERACI \& LOUNSBURY 2005). In addition, ship strikes are becoming more common (VAN WAEREBEeK et al. 2007, BezAMAT et al. 2014), and the influence of geomagnetic topography on marine mammal strandings should also not be disregarded (KLINOWSKA 1985).

Marine currents and coastal winds can interfere with carcass drift and stranding location (Peltier et al. 2012). Previous 
studies have suggested that only about $8 \%$ of small cetaceans that die at sea end up stranding in coastal areas (PeLtier et al. 2012, Prado et al. 2013). According to Peltier et al. (2012), the number of dead cetaceans that reach the coastline and get stranded depend on several parameters such as currents, distance from the coast, atmospheric pressure, wind speed and carcass buoyancy. Coastal species are less influenced by marine currents and coastal winds, commonly stranding near their home ranges (Pyenson 2010, 2011, Prado et al. 2013). However, for areas with strong wind and wave dynamics, such as the cold fronts that occur in southern Brazil (RoDRIGUEs et al. 2004), carcass drift may play a large role in the stranding dynamics.

The ecological relevance of stranding data is often unknown and underestimated. This is due to several factors such as the geographical origin of a sample is not always known, the statistical credibility of stranding data is disputed, and mostly, because sampling is commonly opportunistic in nature (PeLTiER et al. 2012). The reliability and validity of stranding data is highly dependent on a dependable network of collaborators, long sampling periods and systematic and uniform collection efforts in a certain area. The lack of systematic and uniform collection efforts may jeopardize inferences of populational parameters (Peltier et al. 2013). However, studies focused on biodiversity records can still be performed if efforts take into account a large sampling period and a solid network of informants and collaborators. If the network is stable throughout the years, even estimations of frequency of occurrence of certain species might be reliable (Pyenson 2010).

In Southern Brazil, in particular in Santa Catarina state, inventories of marine mammal biodiversity started in the 1980s with the recovery of stranded animals along a $670 \mathrm{~km}$ long coastline (Simões-Lopes \& Ximenez 1993, Simões-Lopes et al. 1995, CHerem et al. 2004). Most efforts were non-systematic and opportunistic due to the topography of the coastline and the non-continuous beaches. However, a broad network of collaborators involving city council members, life-guards, firefighters, fishermen, environmental officers and members of the public ensured a reliable coverage of the coast. Santa Catarina is one of the tourist hotspots in Brazil, and it is often common that strandings of whales and dolphins will also be reported in the media as they happen.

Over 36 species of odontocete cetaceans are known to occur in Brazilian waters (Rocha-CAmpos \& CAmara 2011). In Santa Catarina, CHEREm et al. (2004) reported the occurrence of 19 species, representing $52 \%$ of the marine mammal biodiversity known for the Brazilian coast. Some of these species are globally distributed, such as the sperm whale, Physeter macrocephalus (Linnaeus, 1758), bottlenose dolphin, Tursiops truncatus (Montagu, 1821), and killer whale, Orcinus orca (Linnaeus, 1758) (JefFerson et al. 1993). Other species, on the other hand, have a more restricted distribution, such as Guiana dolphins, Sotalia guianensis (Van Benédén, 1864) (Borobia et al. 1991) and franciscanas, Pontoporia blainvillei (Gervais \& d' Orbigny, 1844) (Crespo et al. 1998, NetTo \& Siciliano 2007).
This study aimed to perform a preliminary assessment of a long-term inventory of odontocete cetaceans' opportunistic strandings throughout the coast of the state of Santa Catarina, southern Brazil, through the analyses of scientific collections and museum databases. In addition to reviewing 32 years of stranding records, this study analyzed the stranding dynamics of three coastal species commonly recorded in this region: $P$. blainvillei, T. truncatus, and S. guianensis.

\section{MATERIAL AND METHODS}

The Santa Catarina mainland coastline is $670 \mathrm{~km}$ long, which is increased to $915 \mathrm{~km}$ if the perimeter of the adjacent islands is also considered. This area is located between $25^{\circ} 58^{\prime} 34^{\prime \prime} \mathrm{S}$ and $29^{\circ} 19^{\prime} 30^{\prime \prime}$ S. In this study, the coastline was divided into three main areas following regional coastal geomorphology and the presence of established research teams. These regions were: north [from Itapoá to Porto Belo, including Babitonga Bay $\left(25^{\circ} 58^{\prime} 34^{\prime \prime} \mathrm{S}, 48^{\circ} 35^{\prime} 58^{\prime \prime} \mathrm{W}\right.$ to $\left.27^{\circ} 13^{\prime} 05^{\prime \prime} \mathrm{S}, 48^{\circ} 36^{\prime} 06^{\prime \prime} \mathrm{W}\right)$ ]; central [from Tijucas to Garopaba $\left(27^{\circ} 13^{\prime} 03^{\prime \prime} \mathrm{S}, 48^{\circ} 36^{\prime} 09^{\prime \prime} \mathrm{W}\right.$ to $\left.28^{\circ} 07^{\prime} 08^{\prime \prime} \mathrm{S}, 48^{\circ} 38^{\prime} 03^{\prime \prime} \mathrm{W}\right)$ ]; and south [from Imbituba to Passo de Torres (28 $07^{\prime} 08^{\prime \prime} \mathrm{S}, 48^{\circ} 38^{\prime} 03^{\prime \prime} \mathrm{W}$ to $\left.29^{\circ} 19^{\prime} 30^{\prime \prime} \mathrm{S}, 49^{\circ} 42^{\prime} 42^{\prime \prime} \mathrm{W}\right)$, including Santo Antonio dos Anjos Lagoon] (Fig. 1).

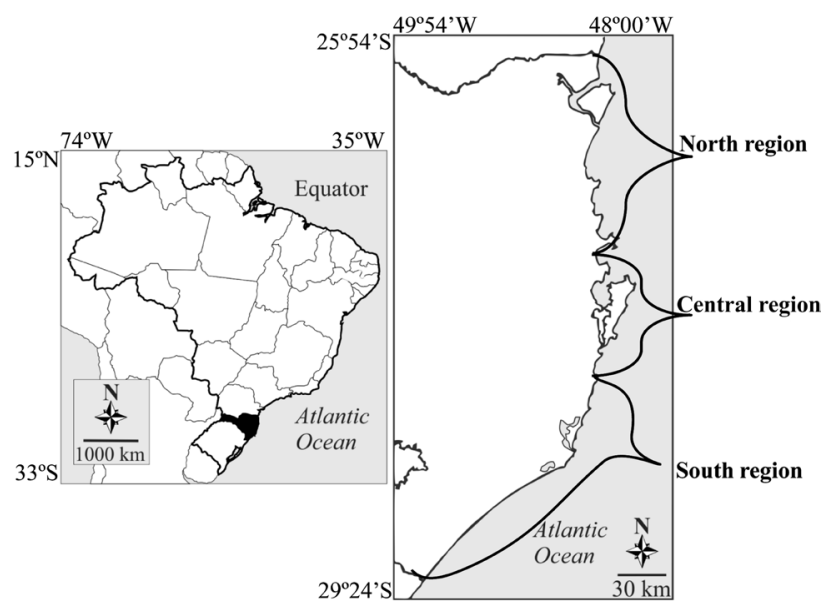

Figure 1. Map showing the location of Santa Catarina state and the three study regions.

In this study, strandings included all episodes in which an animal was found dead or highly debilitated on a beach (GERACI \& Lounsbury 2005, Perrin \& Geraci 2009). Stranding data were obtained through database records from four scientific collections/ museums in the region: Universidade Federal de Santa Catarina (UFSC); Universidade da Região de Joinville (UNIVILLE); Universidade do Estado de Santa Catarina (UDESC); and Museu de Zoologia Professora Morgana Gaidzinski, Universidade do Extremo Sul Catarinense (UNESC). The Sistema de Monitoramento de Mamíferos Marinhos (SIMMAM) database was also consulted, 
along with online mainstream media reports for 1983-2014. Special care was taken with these sources to avoid data duplicity. The collection effort and sampling record of each source is listed below: UFSC (1983-2014) = 223 strandings; UNIVILLE (20002013 $)=147$; UNESC $(2001 / 2003 / 2005-08 / 2010)=21$; UDESC $(2009-2014)=57$; SIMMAM $(1992 / 1994-97 / 2001 / 2003)=09$; Media reports $(2007 / 2010 / 2011)=03$.

External macroscopic assessments were performed on all carcasses analyzed. In some cases, potential causes of death were ascertained during necropsy. Gillnet marks throughout the body consistent with entanglement, or large hematomas and associated fractures suggesting collision with fishing boats, were used to define presumed anthropogenic mortality. Pathological findings observed during opportunistic necropsies conducted by veterinarians, or confirmed after histopathological tests, were also considered. During these opportunistic necropsies led by veterinarians, particularly from 2000 onwards, samples of internal organs (e.g., lungs, heart, liver, kidneys, lymph nodes, and gonads) were collected for histopathological analyses. When the causes of death could not be determined due to advanced decomposition or other circumstances, they were defined as unknown. Sex was determined during necropsy. Sex determination was often not possible with decomposed carcasses.

Data from recent systematic monitoring efforts were also used in this research. From 2012 to 2014, fortnightly systematic collection efforts were performed in the north (UNIVILLE $26^{\circ} 14^{\prime} 06^{\prime \prime} \mathrm{S}, 48^{\circ} 30^{\prime} 06^{\prime \prime} \mathrm{W}$ to $26^{\circ} 20^{\prime} 36^{\prime \prime} \mathrm{S}, 48^{\circ} 34^{\prime} 08^{\prime \prime} \mathrm{W}$ ) and south study regions (UDESC, $28^{\circ} 09^{\prime} 20^{\prime \prime} \mathrm{S}, 48^{\circ} 39^{\prime} 16^{\prime \prime} \mathrm{W}$ to $28^{\circ} 51^{\prime} 51^{\prime \prime} \mathrm{S}$, $\left.49^{\circ} 16^{\prime} 02^{\prime \prime} \mathrm{W}\right)$ through beach surveys.

\section{RESULTS}

\section{Strandings overview}

There were 460 stranding records of toothed whales observed between 1983 and 2014. Four odontocete families were registered: Delphinidae, Phocoenidae, Physeteridae and Pontoporiidae (Table 1). An average of 14 strandings per year was recorded, with a marked increase from 2000 onwards (Fig. 2). This increase reflects an increment in collection efforts from different scientific collections during various periods, which sometimes overlapped. During the last 15 years (2000-2014), when collection efforts were more active and consistent, an average of 22 strandings was registered per year. An evident seasonal variation was observed, with potential collinear effects from cold fronts, as most of the strandings were being recorded during winter and spring months, from July to October (Fig. 3).

Stranding of Risso's, Grampus griseus (G. Cuvier, 1812), and Fraser's dolphins, Lagenodelphis hosei (Fraser, 1956), striped dolphins, Stenella coeruleoalba (Meyen, 1833), and Burmeister's porpoises, Phocoena spinipinnis Burmeister, 1865, were extremely rare. Similarly, records of killer whales, O. orca, false killer whales, Pseudorca crassidens (Owen, 1846), and long-finned pilot whales, Globicephala melas (Traill, 1809), were also sparse. The three spe-
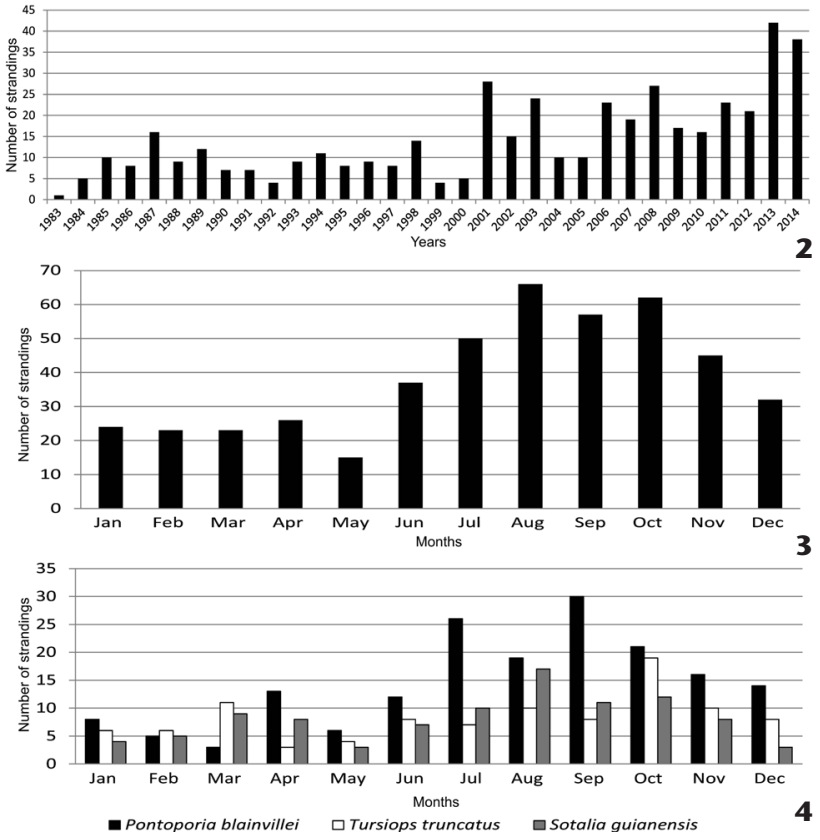

Figures 2-4. (2) Number of odontocete cetacean stranding records per year in Santa Catarina from 1983 to 2014. (3) Seasonal variation in odontocete cetaceans stranding records. (4) Seasonal variation in stranding records of Pontoporia blainvillei, Tursiops truncatus, and Sotalia guianensis.

Table 1. Number of strandings of odontocete cetaceans recorded in the Santa Catarina coast, southern Brazil, from 1983 to 2014. Species names follow the Commitree on TAXonomy (2015).

\begin{tabular}{llr}
\hline \multicolumn{1}{c}{ Family/Species } & \multicolumn{1}{c}{ Commom name } & Total \\
\hline Delphinidae & Common dolphin & 274 \\
Delphinus sp. & Long-finned pilot whale & 23 \\
Globicephala melas (Trail, 1809) & Rissos's dolphin & 2 \\
Grampus griseus (G. Cuvier, 1812) & Fraser's dolphin & 1 \\
Lagenodelphis hosei (Fraser, 1956) & Killer whale, Orca & 1 \\
Orcinus orca (Linnaeus, 1758) & False killer whale & 2 \\
Pseudorca crassidens (Owen, 1846) & Guiana dolphin & 3 \\
Sotalia guianensis (Van Bénedén, 1864) & Clymene dolphin & 97 \\
Stenella clymene (Gray, 1850) & Striped dolphin & 2 \\
Stenella coeruleoalba (Meyen, 1833) & Atlantic spotted dolphin & 23 \\
Stenella frontalis (G. Cuvier, 1829) & - & 6 \\
Stenella sp. & Rough toothed dolphin & 13 \\
Steno bredanensis (G. Cuvier, 1828) & Common bottlenose dolphin & 100 \\
Tursiops truncatus (Montagu, 1821) & & 1 \\
Phocoenidae & Burmeister's porpoise & 1 \\
Phocoena spinipinnis Burmeister, 1865 & & 12 \\
Physeteridae & Pygmy sperm whale & 5 \\
Kogia breviceps (Blainville, 1838) & - & 173 \\
Kogia sp. & Sperm whale, cachalot & 6 \\
Physeter macrocephalus Linnaeus, 1758 & & 173 \\
Pontoporiidae & Franciscana, Toninha & \\
Pontoporia blainvillei (Gervais \& d'Orbigny, 1844) & \\
\hline & & 1 \\
\hline
\end{tabular}

ZOOLOGIA 33(5): e20160089 | DOI: 10.1590/S1984-4689zool-20160089 | October 3, 2016 
cies with the most frequent stranding records were $P$. blainvillei $(\mathrm{n}=173)$, T. truncatus $(\mathrm{n}=100)$ and S. guianensis $(\mathrm{n}=97)$ (Table 1). These species stranded more frequently in the second half of the year. Franciscanas, in particular, had $72.8 \%$ of their stranding records during the winter months. Bottlenose dolphins and Guiana dolphins had $62.8 \%$ and $62 \%$ of their strandings during the second half of the year, respectively (Fig. 4).

During the last three decades, the non-systematic and opportunistic stranding records analyzed showed little evidence of a clearly defined pattern in the stranding records of franciscanas, bottlenose and Guiana dolphins. Franciscanas had few stranding records during the 1990s, while bottlenose and Guiana dolphins had an irregular stranding pattern throughout the years. For these three species, most of the strandings were recorded from 2000 onwards, when collection efforts and communication networks were more active (Fig. 2). If considering only the period from 2012 to 2014, when collection efforts were more active and consistent, the number of strandings tripled from about 10 to 30 strandings per year.

\section{Sexual distribution}

For the three species recorded most commonly, there was a large number of specimens of unknown sex due to carcass decomposition, which prevented sex determination. For the specimens with known sex, there was a significantly higher mortality of females of franciscanas $(\mathrm{F}=46 ; \mathrm{M}=26 ; 1,77 \mathrm{~F}: 1 \mathrm{M}$; $\mathrm{p}=0.0184)$ and males of Guiana dolphins $(\mathrm{F}=27 ; \mathrm{M}=46$; $0,58 \mathrm{~F}: 1 \mathrm{M} ; \mathrm{p}=0.0262$ ). For bottlenose dolphins, the difference between strandings of males and females was not significant $(\mathrm{F}=26 ; \mathrm{M}=32 ; 0,81 \mathrm{~F}: 1 \mathrm{M} ; \mathrm{p}=0.4308)$ (Fig. 5).

\section{Spatial distribution}

Strandings of franciscanas and bottlenose dolphins were registered throughout the coast. Most stranding records were distributed heterogeneously as observed during opportunistic sampling efforts throughout the years (Figs. 5-8). Strandings of franciscanas were observed both in Babitonga Bay, and also in more exposed areas. The distribution of strandings was continuous along the coast, with no gaps. Strandings of bottlenose dolphins were recorded in open water areas and also in estuarine regions, including Santo Antonio dos Anjos Lagoon in Laguna. Records of Guiana dolphins were observed within the known distribution of the species, of which Florianópolis (Santa Catarina Island) is in its southernmost distribution (Figs. 6-8). Non-systematic stranding records of this species suggest two main populations, one in Babitonga Bay and another in North

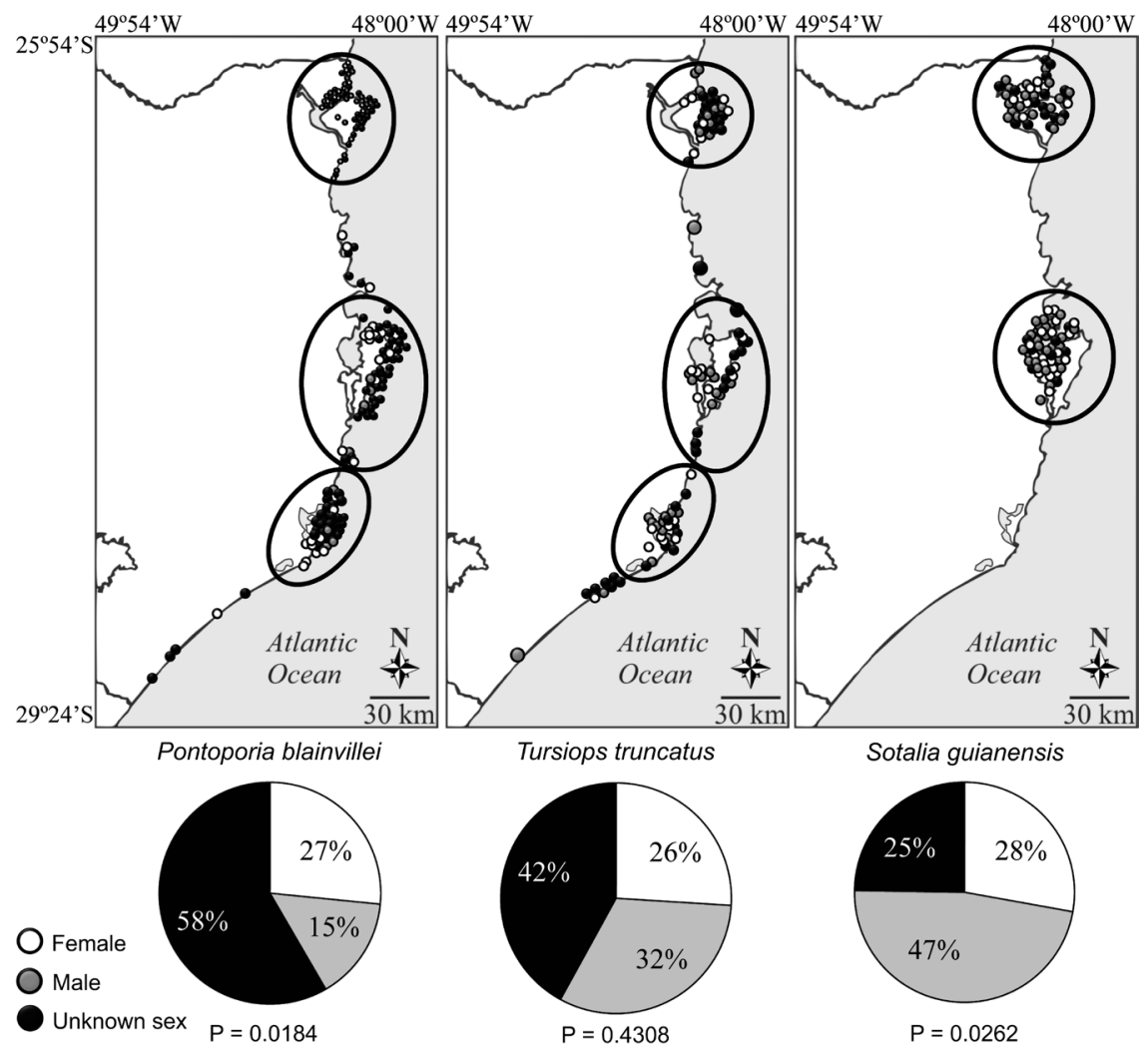

Figure 5. Spatial and sexual distribution of stranding records of Pontoporia blainvillei, Tursiops truncatus and Sotalia guianensis along Santa Catarina coast from 1983 to 2014. 


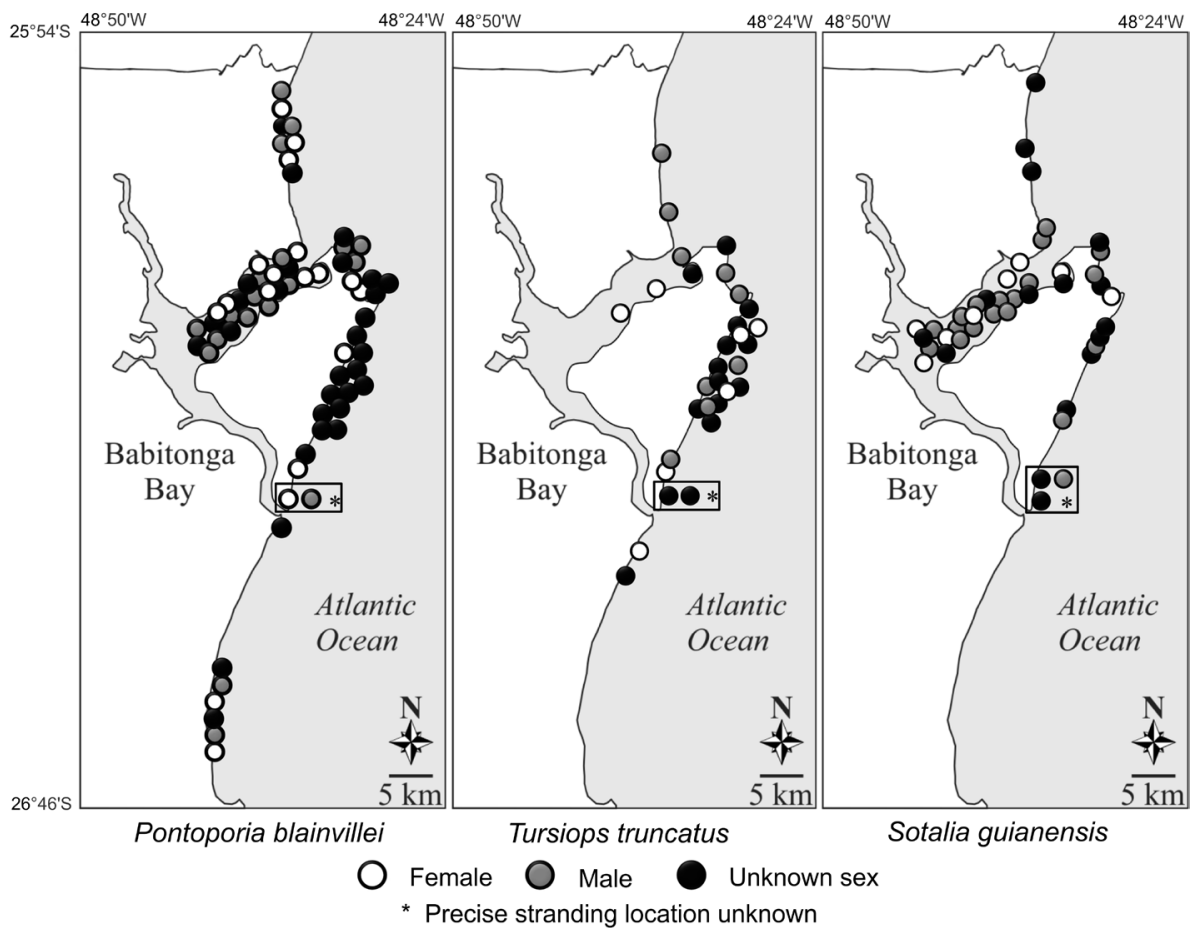

Figure 6. Spatial distribution of strandings of Pontoporia blainvillei, Tursiops truncatus, and Sotalia guianensis in the north region from 1983 to 2014.

Bay in Florianópolis, mostly in sheltered areas of those bays. No records were observed in between these two areas (Figs. 6-7).

\section{Causes of death}

Most of the specimens could not have their causes of death determined due to advanced decomposition of the carcasses, or circumstances were not apparent $(n=283)$. In the cases where the presumed cause of death could be ascertained $(n=110)$, anthropogenic mortality due to fisheries interactions were common $(n=104)$. These were defined through the presence of gillnet marks throughout the body consistent with entanglement, or large hematomas and associated fractures suggesting collision with fishing boats. Few specimens had diseases and pathologies as confirmed causes of death $(n=6)$, possibly due to the scarcity of veterinary assessments during post-mortem examinations.

\section{DISCUSSION}

\section{Diversity}

The 460 stranding records evaluated included 17 odontocete species. Some of these are oceanic and rarely seen near the coast (e.g., L. hosei, G. griseus, S. coeruleoalba, Clymene dolphin, Stenella clymene (Gray, 1850), which explains their low record numbers. Stenella clymene and S. coeruleoalba have been observed in rare occasions on the continental shelf of Southern Brazil and Argentina (Moreno et al. 2005, Do Amaral et al. 2015).
Other oceanic species such as the Pygmy sperm whale, Kogia breviceps (Blainville, 1838), P. macrocephalus and P. crassidens have been observed recurrently throughout the years. The coast of Santa Catarina is one of the only places in Brazil where living sperm whales have been observed, and strandings of males, females and juveniles have also been recorded (Simões-Lopes \& Ximenez 1993, Ramos et al. 2001, Cherem et al. 2004). Resurgence currents near Santa Marta Cape and the high biological productivity in this region (CAMPos et al. 2013) could be related to sperm whale sightings in Santa Catarina. Dwarf sperm whales, Kogia sima (Owen, 1866), were recorded only once in the region through a stranded specimen from Itajaí, in the north study area (specimen number MOVI 05587) (CHEREM et al. 2004), although strandings were relatively frequent in the warm waters of the northeastern Brazilian coast (Moura et al. 2016). Another two oceanic species which have been registered for Santa Catarina, but without associated museum specimens and thus not reported here, were two elusive beaked whales: Southern bottlenose whale, Hyperoodon planifrons Flower, 1882, and Blainville's beaked whale, Mesoplodon densirostris (Blainville, 1817) (SIMÕES-LOPES \& XIMENEZ 1993). Strandings of killer whales are rare in Santa Catarina, but sightings are becoming more common. One previous record of a P. spinipinnis likely represents an extra-limit record, although the stranding location is still under the influence of the Malvinas current (SIMÕES-LOPES \& XIMENEZ 1989). 


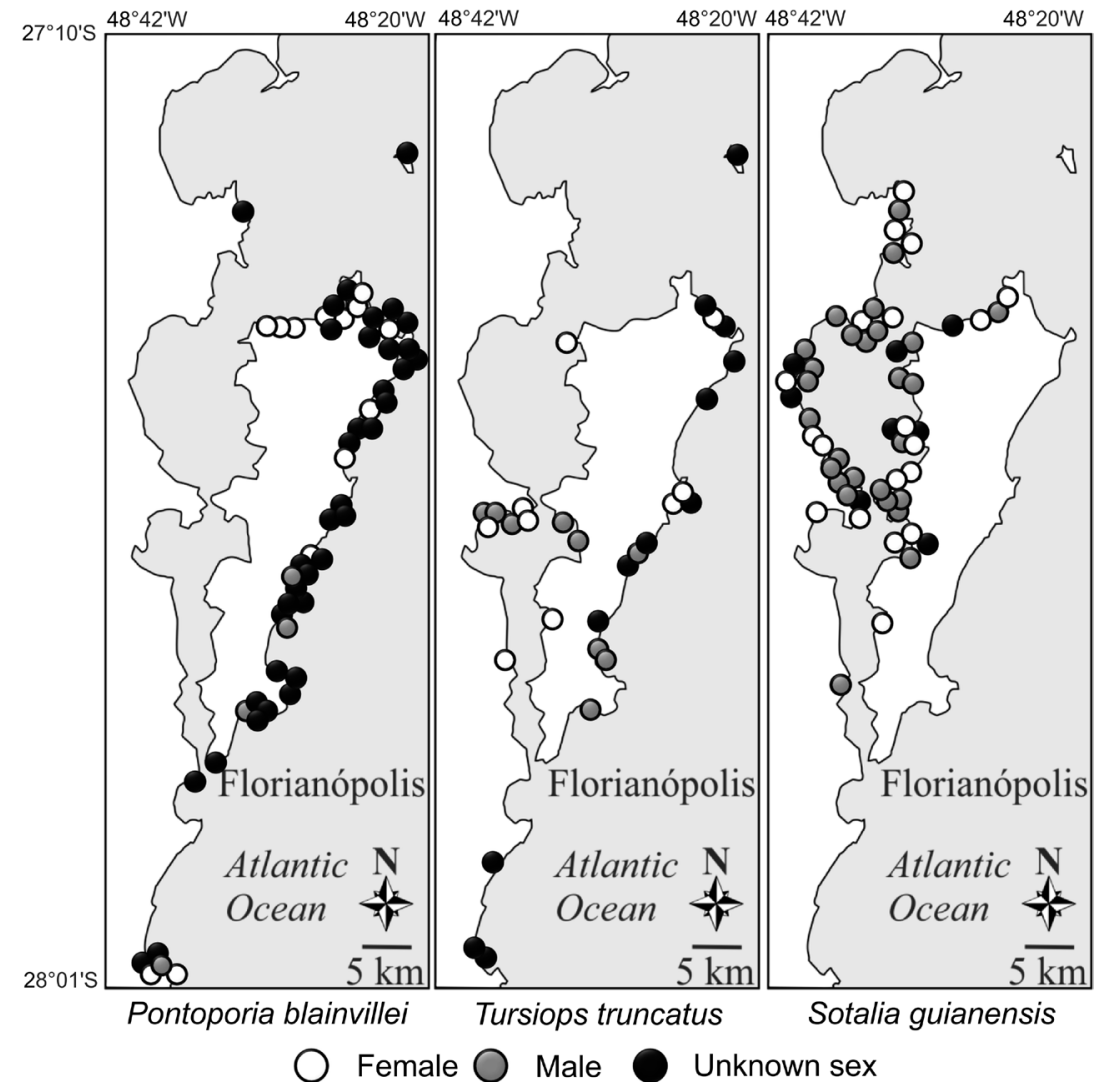

Figure 7. Spatial distribution of strandings of Pontoporia blainvillei, Tursiops truncatus, and Sotalia guianensis in the central region from 1983 to 2014.

Coastal species are 50 times more likely to strand than offshore species due to less influence from winds and carcass drift (Peltier et al. 2012). However, the drift rate was unknown for the study area and debilitated animals may have drifted before dying locally. This would be the case for specimens of franciscanas, Guiana dolphins and bottlenose dolphins. Spotted dolphins, Stenella frontalis (G. Cuvier, 1829), common dolphins, Delphinus capensis Gray, 1828, and rough-toothed dolphins, Steno bredanensis (G. Cuvier, 1828), are often considered offshore species, but the reasonably high number of strandings reported here could indicate coastal habits for these species during certain times of the year. The high influence of the Subtropical Confluence and its mixing of waters along the coast of Santa Catarina state (GoRDON 1989) would be a strong reason for the occurrence of these species within this region. Spotted dolphins are common throughout the south and southeast of Brazil, with confirmed sightings along the continental shelf mainly between $20.5^{\circ} \mathrm{S}$ and $30^{\circ} \mathrm{S}$ (Moreno et al. 2005, do Amaral et al. 2015).

\section{Frequency and seasonality of strandings}

There seems to have been an increment in the number of odontocete strandings throughout Santa Catarina coast during the last 32 years. This increase can be related to an expansion in collection efforts and more consistent collaboration networks, together with a possible increase in fisheries bycatch (e.g., Prado et al. 2013). In this study, P. blainvillei had most stranding records in July and September during the austral winter. FERREIRA et al. (2010) observed a similar temporal pattern for strandings of franciscanas in the coast of Rio Grande do Sul, south of Santa Catarina. SANTOS et al. (2002) reported a corresponding temporal trend for the coast of São Paulo state, with most records being observed in July/August, but also in November/December. The decrease in franciscana strandings in the 1990s and subsequent increase in the 2000s could be associated with a decline in productivity in artisanal fisheries and an associated increase in industrial fisheries since early 1980s (CEPSUL/ICMBio 2015).

Sotalia guianensis had most of their strandings during the second half of the year, peaking in August during the austral winter. At the southernmost limit of its distribution, this species has a resident population which was observed to have increased movements during winter (WedekIN et al. 2007). The wider distribution of this species during winter should be taken into consideration; however, the increased fisheries activities in the region should not be ignored. For both north and central 


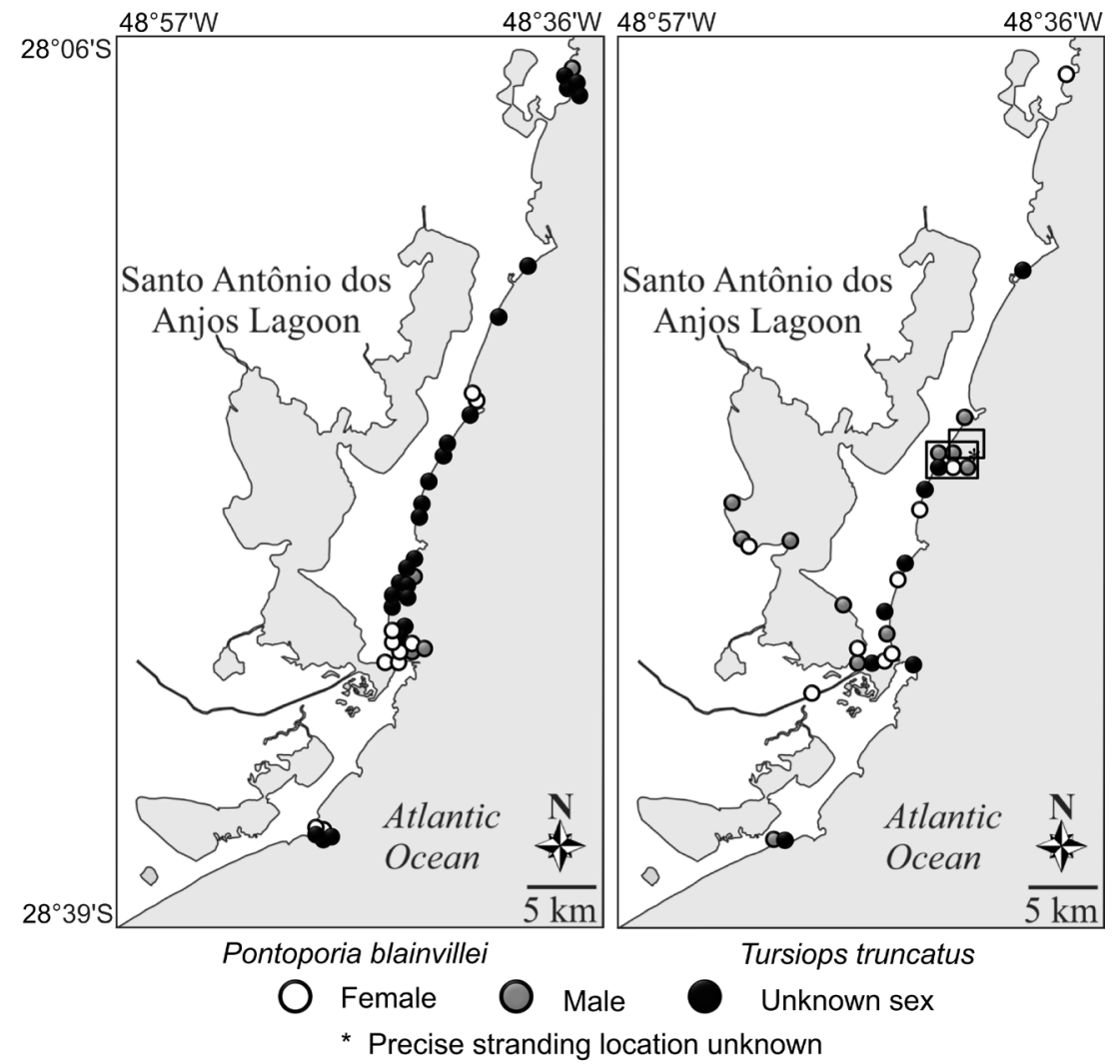

Figure 8. Spatial distribution of strandings of Pontoporia blainvillei and Tursiops truncatus in the south region from 1983 to 2014.

regions, there was an increase in strandings in the first half of the year, mainly during March and April. A similar trend was observed by Meirelles et al. (2010) for the coast of Ceará state, in the northeastern region of Brazil.

Tursiops truncatus had most of its stranding records in the second half of the year, peaking in October during the austral spring. A similar pattern of strandings throughout the year was reported by FruET et al. (2012) to Rio Grande do Sul, the southernmost state of Brazil. Fruet et al. (2012) observed a higher number of strandings during spring and summer. While these authors reported the winter as the season with lowest stranding records of bottlenose dolphins in Rio Grande do Sul, autumn was the season with less strandings in the current study.

\section{Most common coastal species}

Franciscanas had the highest number of strandings with 173 records to the coast of Santa Catarina. In the north study region, franciscanas have been observed throughout the year both inside Babitonga Bay and also in the adjacent coastal areas (CREMER \& SimÕES-Lopes 2005). It is thought that franciscanas have a continuous distribution both throughout the coast of Santa Catarina and the southern region of Brazil (CHERem et al. 2004), and have been more commonly observed near the $20 \mathrm{~m}$ depth curve (SECCHI et al. 2003). The species is rarely observed within both the North and South Bays in Florianópolis (FLORES 2009). The non-systematic stranding records analyzed in this study suggest that the species is distributed throughout the coast, which makes it unlikely that there is a distribution hiatus as previously thought (SECCHI et al. 1998). The species has been confirmed as occurring in the south region of study near the coastal town of Rincão (ASB Campos, pers. comm.), where it was previously thought as non-occurring. The differences in stranding numbers among study regions likely reflect unequal collection efforts in these areas.

Bottlenose dolphins were the species with the second largest number of strandings, with 100 records along the coast of Santa Catarina. Non-systematic stranding records appeared to be uniformly distributed throughout the coast, mirroring the species distribution (WEDEKIN et al. 2008). The lower number of stranding records for the southernmost region of study, next to Rio Grande do Sul state $(\mathrm{n}=1)$, reflects less monitoring and collection efforts in this region. Recent taxonomic reviews about the existence of two ecotypes within the genus Tursiops, an offshore and a coastal form, suggest that strandings of the bottlenose dolphin in Santa Catarina may include both forms, now considered subspecies: $T$. t. truncatus and T. t. gephyreus (CosTA et al. 2016). 
Guiana dolphins had the third highest number of strandings ( $n=97$ ). Records were concentrated within the north and central study regions, where the two only known populations of the species in Santa Catarina occur (CREMER et al. 2011). Records from the north region corresponded mostly to the area of Babitonga Bay, where HARDT et al. (2010) have reported the existence of a resident population. In the central region, most records correspond to the North Bay in Florianópolis, the southernmost limit of distribution of this species (SIMÕES-LOPES 1988). The occurrence of eight stranding records in the South Bay in Florianópolis may be related to carcass drift due to internal north/south currents within the bays. Previous studies have showed that sightings of the species are frequent in the northwest region of the North Bay, despite some animals having been observed in the west and southwest areas of this region (WEDEKIN et al. 2010).

\section{Sexual distribution of strandings and presumed causes of death}

Although many specimens were classified as undetermined sex due to decomposition of carcasses, differences in the number of strandings between males and females were statistically significant for franciscanas and Guiana dolphins. For franciscanas, the number of strandings of females was higher than that of males $(1,77 \mathrm{~F}: 1 \mathrm{M}, \mathrm{p}=0.0184)$. Conversely, SANTOS et al. (2002) reported a higher proportion of male strandings for franciscanas in the coast of São Paulo state. For Guiana dolphins, the higher number of stranded males $(0,58 \mathrm{~F}: 1 \mathrm{M}, \mathrm{p}=0.0262)$ was also different from studies in other regions of the Brazilian coast, suggesting a high prevalence of female strandings (Moura et al. 2009, MeirelLes et al. 2010).

There were no significant differences between strandings of males and females of the bottlenose dolphin. Conversely, FrUET et al. (2012) reported a ratio of $1 \mathrm{~F}: 1,8 \mathrm{M}$ for the coast of Rio Grande do Sul, south of Santa Catarina. The findings of our research are in accordance with studies developed elsewhere which report similar sex ratios for strandings (0,92F:1,00M in South Carolina, USA, McFeE et al. 2006). The high number of carcasses of undetermined sex in this study could be related to offshore carcass drift leading to accelerated decomposition and consumption by scavengers. Strandings in isolated beaches could also have an influence on carcass recovery time allowing for advanced decomposition and difficulty in sex determination.

The $27 \%$ of the stranding records with presumed cause of death known were likely caused by anthropogenic causes such as fisheries interactions. The high number of strandings of franciscanas in July may be related to blue fish, mullet, and manjuva fisheries, which are active during this time of the year. White croacker, Micropogonias furnieri (Desmarest, 1823), fisheries take place in this region from August to December, a factor that could contribute to a high number of strandings in September (DAura-Jorge et al. 2007). The latter authors also mention that drift nets are commonly used for this fishery, with mesh sizes averaging 8 to $9 \mathrm{~mm}$. Ferreira et al. (2010) reported a high number of franciscana strandings for the Rio Grande do Sul coast during spring, with a high number of incidental bycatches occurring when white croacker fisheries were more active. Although some of the target species for fisheries are not part of the diet of franciscanas, these animals often end up caught in commercial fishing nets. There is a great diversity of fishing nets and fishing methods employed in commercial fisheries, including fixed nets that remain in the same area for several days, or drift nets that are left afloat (DAURA-Jorge et al. 2007). Pinheiro \& CRemer (2003) also reported a high number of franciscana strandings in September, due to the increase in fishing activity during spring and summer.

The high number of strandings of Guiana dolphins for the north region during spring and summer also corroborates the findings of Pinheiro \& Cremer (2003) for the same region. A higher number of strandings during winter months was observed by Meirelles et al. (2010) on the coast of Ceará state, also on the northeastern coast of Brazil. The latter authors suggest the high mortality during this time could be related with fisheries bycatch, since this is one of the periods of the year with stronger fishing activity. In this study, the high mortality of Guiana dolphins in winter months in the central region can also be related with fisheries, since white croacker, manjuva, mullet and shrimp fishing boats are active in winter. These fisheries often use fixed, trawling and purse-seine nets afloat (DAURA-Jorge et al. 2007).

Most opportunistic stranding records of bottlenose dolphins were observed during the second half of the year. These strandings could be related with mullet migration, which takes place during winter. Other fish such as bluefish, Pomatomus saltatrix (Linnaeus, 1766), white croacker, and shrimp are also active during this period, as suggested by FrUET et al. (2012) to the coast of Rio Grande do Sul. Fruet et al. (2012) mentioned that artisanal fisheries are active throughout the year for the Rio Grande do Sul coast; however, most fishing efforts are concentrated between October and March when there is also a considerable increase in stranding numbers.

Past studies have shown that it is difficult to characterize and quantify the influence of fishing activities in marine mammal bycatch and subsequent strandings (Goodall et al. 1994, Siciliano 1994, Mäder et al. 2006, ReAD et al. 2006, Meirelles et al. 2009). Often these studies mention the need for broader and more consistent monitoring and collection efforts, and the wider understanding of other factors that also may be contributing to marine mammal mortality in a given region.

Although our study showed a high percentage of animals with unknown causes of death, almost $1 / 3$ of the stranding records were presumably related to negative fisheries interactions. This suggests that anthropogenic factors play a major role in marine mammal mortality and the impact of these interactions could be underestimated. In particular, populations of franciscanas are considered vulnerable (IUCN 2015). This conservation status has been reinforced by previous studies also for the Guiana dolphin, although its status is classified as data deficient by the 
IUCN (Simões-Lopes \& Ximenez 1993, Corcuera et al. 1994, Crespo et al. 1994, Pinedo 1994, Pinedo \& Polacheck 1999, Pinheiro \& Cremer 2003). For these species, consistent monitoring and collection efforts would highly benefit the understanding of populational trends and other conservation implications.

\section{FINAL CONSIDERATIONS}

Pontoporia blainvillei (173 specimens), T. truncatus (100 specimens) and $S$. guianensis (97 specimens) were the small cetaceans most commonly recorded from 1983 to 2014. Most non-systematic stranding records were observed during the second half of the year and almost $1 / 3$ of the strandings were presumably related to anthropogenic causes, mainly fisheries interactions. The majority of the stranding records could not have the presumed cause of death determined due to advanced carcass decomposition. The analyses of non-systematic collection efforts revealed that Franciscanas had stranding records distributed throughout the coast of Santa Catarina, mainly observed during winter and spring. Strandings of Guiana dolphins were only observed in the north and central regions, where resident populations inhabit coastal bays. Most stranding records of this species were observed during winter, but also during spring. Bottlenose dolphins had continuous stranding records along the coast, with most records registered during spring and late summer, as other past studies have previously reported.

While the focus of this study was a preliminary assessment of stranding data obtained through opportunistic collection, it is evident that future systematic monitoring efforts and stable networks of collaborators will generate more reliable coastal biodiversity inventories and will allow the understanding of populational parameters of the species studied. Future studies using more refined statistical analyses such as linear and generalized mixed models should be employed to elucidate the stranding rates of cetaceans and associated spatial-temporal dynamics. These are essential to understand species occurrence and to validate management strategies, informing conservation policies and contributing to a greater knowledge of the marine and coastal ecosystems within this region.

\section{ACKNOWLEDGEMENTS}

We are indebted to the following collections for allowing us to access their stranding records: Universidade Federal de Santa Catarina (UFSC); Universidade da Região de Joinville (UNIVILLE); Universidade do Estado de Santa Catarina (UDESC) and Museu de Zoologia Professora Morgana Gaidzinski, Universidade do Extremo Sul Catarinense (UNESC). Thanks are also extended to all collaborators, interns and volunteers (past and current) of these collections for their effort in recovering and preparing carcasses. Thanks are also extended to two anonymous reviewers whose suggestions greatly improved this manuscript, and to Glynny Kieser for her valuable editorial and proofreading support.

\section{LITERATURE CITED}

Bezamat C, Wedekin LL, Simões-Lopes PC (2014) Potential ship strikes and density of humpback whales in the Abrolhos Bank breeding ground, Brazil. Aquatic Conservation: Marine and Freshwater Ecosystems 25: 712-725. doi: 10.1002/aqc.2523

Borobia M, Siciliano S, Lodi L, Hoek W (1991) Distribution of the South American dolphin Sotalia fluviatilis. Canadian Journal of Zoology 69: 1025-1039. doi: 10.1139/z91-148

Campos PC, Möller Jr OO, Piola AR, Palma ED (2013) Seasonal variability and coastal upwelling near Cape Santa Marta (Brazil). Journal of Geophysical Research Oceans 118: 1420-1433. doi: 10.1002/jgrc.20131,2013

CEPSUL/ICMBıo. 2015. Estatística por ano. Available online at: http://www.icmbio.gov.br/cepsul/biblioteca/acervo-digital/111-estatistica.html [Accessed: 01/06/2015]

Cherem J, Simões-Lopes PC, Althoff S, Graipel M (2004) Lista dos mamíferos do estado de Santa Catarina, Sul do Brasil. Mastozoologia Neotropical 11: 151-184.

COMMITTE ON TAXONOMY (2015) List of marine mammal species and subspecies. Society for Marine Mammalogy, available online at: https://www.marinemammalscience.org/species-information/ list-marine-mammal-species-subspecies [Accessed: 01/05/2016]

Corcuera JF, Monzon F, Crespo E A, Aguilar A, Raga JA (1994) Interactions between marine mammals and the coastal fisheries of Necochea and Claromecó (Buenos Aires province, Argentina), p. 283-290. In: Perrin W, Donovan GP, Barlow J (Eds.) International Whaling Commission: Gillnets and Cetaceans. Cambridge, Black Bear, 629p.

Costa APB, Rosel PE, Daura-Jorge FG, Simões-Lopes PC (2016) Offshore and coastal common bottlenose dolphins of the western South Atlantic face-to-face: What the skull and spine can tell us. Marine Mammal Science. doi: 10.1111/mms.12342

Cremer MJ, Simões.-Lopes PC (2005) The occurrence of Pontoporia blainvillei (Gervais \& d'Orbigny) (Cetacea, Pontoporiidae) in an estuarine area in southern Brazil. Revista Brasileira de Zoologia 22: 717-723. doi: 10.1590/S0101-81752005000300032

Cremer MJ, Hardt FAS, Tonello Jr AJ, Simões-Lopes PC (2011) Distribution and status of the guiana dolphin Sotalia guianensis (Cetacea, Delphinidae) population in Babitonga bay, southern Brazil. Zoological Studies 50: 327-337.

Crespo EA, Corcuera JF, Cazorla AL (1994) Interactions between marine mammals and fisheries in some coastal fishing areas of Argentina, p. 268-281. In: Perrin W, Donovan GP, Barlow J (Eds.) International Whaling Commission: Gillnets and Cetaceans. Cambridge, Black Bear, 629p.

Crespo EA, Harris G, González R (1998) Group size and distributional range of the franciscana, Pontoporia blainvillei. Marine Mammal Science 14: 845-849. doi: 10.1111/j.17487692.1998.tb00768.x

Daura-Jorge FG, Wedekin LL, Hanazaki N (2007) A pesca artesanal no mosaico de áreas protegidas do litoral de Santa Catarina. Florianópolis, UFSC, 55p. 
do Amaral KB, Alvares DJ, Heinzelmann L, Borges-Martins M, SiciliaNo S, Moreno IB (2015) Ecological niche modeling of Stenella dolphins (Cetartiodactyla: Delphinidae) in the southwestern Atlantic Ocean. Journal of Experimental Marine Biology and Ecology 472: 166-179. doi: 10.1016/j.jembe.2015.07.013

Ferreira EC, Muelbert MMC, SECChi ER (2010) Distribuição espaço-temporal das capturas acidentais das toninhas (Pontoporia blainvillei) em redes de emalhe e dos encalhes ao longo da costa sul do Rio Grande do Sul, Brasil. Atlântica 32: 183-197. doi: 10.5088/atlântica.v32i2.2468

FloRes PAC (2009) Occurrence of franciscana dolphin (Pontoporia blainvillei) in Baía Norte, southern Brazil. The Latin American Journal of Aquatic Mammals 7: 93-95. doi: 10.5597/ lajam00142

Fruet PF, Kinas PG, Silva KG da, Di Tullio JC, Monteiro DS, Rosa LD, Estima SC, SeCCHI ER (2012) Temporal trends in mortality and effects of by-catch on common bottlenose dolphins, Tursiops truncatus, in southern Brazil. Journal of Marine Biological Association of the United Kingdom 92: 1865-1876. doi: $10.1017 /$ S0025315410001888

Geraci JR, Lounsbury VJ (2005) Marine Mammals Ashore: A Field Guide for Strandings. Baltimore, National Aquarium in Baltimore, 371p.

Goodall RNP, Schiavini ACM, Fermani C (1994) Net fisheries and net mortality of small cetaceans off Tierra del Fuego, Argentina, p. 295-304. In: Perrin W, Donovan GP, Barlow J (Eds.) International Whaling Commission: Gillnets and Cetaceans. Cambridge, Black Bear, 629p.

Gordon AL (1989) Brazil-Malvinas Confluence 1984. Deep Sea Research Part A. Oceanographic Research Papers 36: 359384. doi: 10.1016/0198-0149(89)90042-3

Hardt FAS, Cremer MJ, Tonello Jr AJ, Simões-Lopes PC (2010) Residence patterns of the Guiana dolphin Sotalia guianensis in Babitonga Bay, south coast of Brazil. The Latin American Journal of Aquatic Mammals 8: 117-121. doi: 10.5597/ lajam00160

IUCN (2015). The IUCN Red List of Threatened Species. Version 2015-4. Available online at: http://www.iucnredlist.org [Accessed: 12/12/2015]

Jefferson TA, Leatherwood S, Webber MA (Ed.) (1993) Marine mammals of the world. Rome, FAO, 320p.

KLINOWSKA M (1985) Cetacean live strandings related to geomagnetic topography. Aquatic Mammals 1: 27-32.

Leeney RH, Amies R, Broderick AC, Witt MJ, Loveridge J, Doyle J, Godley BJ (2008) Spatio-temporal analysis of cetacean strandings and bycatch in a UK fisheries hotspot. Biodiversity and Conservation 17: 2323-2338. doi: 10.1007/ s10531-008-9377-5

Macleod CD, Bannon SM, Pierce GJ, Schweder C, Learmonth JA, Herman JS, ReId RJ (2005) Climate change and the cetacean community of north-west Scotland. Biological Conservation 124: 477-483. doi: 10.1016/j.biocon.2005.02.004

Mäder A, Sander M, Balbão TC (2006) Atividade antrópica asso- ciada à mortalidade de mamíferos marinhos no litoral norte do Rio Grande do Sul. Biodiversidade Pampeana 4: 24-28.

McFee WE, Hopkins-Murphy SR, Schwacke LH (2006) Trends in bottlenose dolphin (Tursiops truncatus) strandings in South Carolina, USA, 1997-2003: implications for the southern North Carolina and South Carolina management units. Journal of Cetacean Research and Management 8: 195-201. Meirelles ACO de, Monteiro-Neto C, Martins AMA, Costa AF, Barros HMDR (2009) Cetacean strandings on the coast of Ceará, north-eastern Brazil (1992-2005). Journal of Marine Biological Association of the United Kingdom 89: 10831090. doi: 10.1017/S0025315409002215

Meirelles ACO de, Ribeiro AC, Silva CPN, Soares-Filho AA (2010) Records of guiana dolphin, Sotalia guianensis, in the state of Ceará, northeastern Brazil. The Latin American Journal of Aquatic Mammals 8: 97-102. doi: 10.5597/lajam00157

MoReno IB (2005) Distribution and habitat characteristics of dolphins of the genus Stenella (Cetacea: Delphinidae) in the Southwest Atlantic Ocean. Marine Ecology Progress Series 300: 239-240. doi: 10.3354/meps300229

Moura JF, Sholl TGC, Rodrigues ES, Hacon S, Siciliano S (2009) Marine tucuxi dolphin (Sotalia guianensis) and its interaction with passive gill-net fisheries along the northern coast of the Rio de Janeiro State, Brazil. Marine Biodiversity Records 2. doi: $10.1017 / \mathrm{S} 1755267209000864$

Moura Jf, Acevedo-Trejos E, Tavares DC, Meirelles AC, Silva CP, Oliveira LR, Santos RA, Wickert JC, Machado R, Siciliano S, Merico A (2016) Stranding events of Kogia whales along the Brazilian coast. Plos One 11: e0146108. doi: 10.1371/journal. pone.0146108

Netto R de F, Siciliano S (2007) Contribuição ao conhecimento da distribuição da toninha Pontoporia blainvillei (Gervais \& d'Orbigny, 1984) no estado do Espírito Santo, Sudeste do Brasil. Boletim do Museu de Biologia Professor Mello Leitão 21: 35-45.

Peltier H, Dabinb W, Danielc P, Vancanneyt O, Dorémusb G, Huon M, Ridoux V (2012) The significance of stranding data as indicators of cetacean populations at sea: Modelling the drift of cetacean carcasses. Ecological Indicators 18: 278-290. doi: 10.1016/j.ecolind.2011.11.014

Peltier H, Baagoe HJ, Camphuysen CJ, Czeck R, Dabin W, Daniel P, Deaville R, Haelters J, Jauniaux T, Jensen LF, Jepson PD, Keij GO, Siebert U, Canneyt OV, Ridoux V (2013) The Stranding Anomaly as Population Indicator: The Case of Harbour Porpoise Phocoena phocoena in North-Western Europe. Plos One 8: e62180. doi: 10.1371/journal.pone.0062180

Perrin WF, Geraci JR (2009) Strandings, p, 1118-1123. In: Perrin WF, WÜrsig B, Thewissen JGM (Eds.) Encyclopedia of Marine Mammals. Amsterdamn Elsevier, $2^{\text {nd }}$ ed.

PINEDo MC (1994) Review of small cetacean fishery interactions in southern Brazil with special reference to the franciscana, Pontoporia blainvillei, p. 251-259. In: PerRIN W, Donovan GP, BARLOW J (Eds.) International Whaling Commission: Gillnets and Cetaceans. Cambridge, Black Bear. 
Pinedo MC, Polacheck T (1999) Trends in franciscana (Pontoporia blainvillei) stranding rates in Rio Grande do Sul, Southern Brazil (1979-1998). Journal of Cetacean Research and Management 1: 179-189.

Pinheiro L, Cremer MJ (2003) Etnoecologia e captura acidental de golfinhos (Cetacea: Pontoporiidae e Delphinidae) na baía da Babitonga, Santa Catarina. Desenvolvimento e Meio Ambiente 8: 69-75.

Pyenson ND (2010) Carcasses on the coastline: measuring the ecological fidelity of the cetacean stranding record in the eastern North Pacific Ocean. Paleobiology 36: 453-480. doi: 10.1666/09018.1

Pyenson ND (2011) The high fidelity of the cetacean stranding record: insights into measuring diversity by integrating taphonomy and macroecology. Proceedings of the Royal Society 278: 3608-3616. doi: 10.1098/rspb.2011.0441

Prado JHF, Secchi ER, KINAS PG (2013) Mark-recapture on endangered franciscana dolphin (Pontoporia blainvillei) killed in gillnet fisheries to estimate past bycatch from time series of stranded carcasses in southern Brazil. Ecological Indicators 32: 35-41. doi: 10.1016/j.ecolind.2013.03.005

Ramos R, Siciliano S, Borobia M, Zerbini AN, Pizzorno JL, Fragoso ABL, Brito Jr JL, Azevedo AF, Simões-Lopes PC, Santos MC de O (2001) A note on strandings and age of sperm whales (Physeter macrocephalus) on the Brazilian Coast. Journal of Cetacean Research and Management 3: 321-327.

ReAd AJ, Drinker P, Northridge S (2006) Bycatch of marine mammals in U.S. and global fisheries. Conservation Biology 20: 163-169. doi: 10.1111/j.1523-1739.2006.00338.x

Rocha-CAmpos CC, CÂmara I DE G (2011) Plano de ação nacional para conservação dos mamíferos aquáticos: grandes cetáceos e pinípedes. Brasília, Instituto Chico Mendes de Conservação da Biodiversidade, 156p.

Rodrigues MLG, Franco D, Sugahara S (2004) Climatologia de frentes frias no litoral de Santa Catarina. Revista Brasileira de Geofísica 22: 135-151. doi: 10.1590/S0102-261X2004000200004

Santos MC de O, Vicente AFC, Zampirolli E, Alvarenga FS, Souza SP (2002) Records of franciscana (Pontoporia blainvillei) from the coastal waters of São Paulo state, southeastern Brazil. The Latin American Journal of Aquatic Mammals 1: 169-174. doi: $10.5597 /$ lajam00024

SeCchi ER, Wang JY, Murray B, Rocha-Campos CC, White BN (1998) Populational differences between franciscanas, Pontoporia blainvillei, from two geographical locations as indicated by sequences of mtDNA control region. Canadian Journal of Zoology 76: 1622-1627.

Secchi ER, Danilewicz D, Ott PH (2003) Applying the phylogeographic concept to identify franciscana dolphin stocks: implications to meet management objectives. Journal of Cetacean Research and Management 5: 61-68.
Siciliano S (1994) Review of small cetaceans and fishery interactions in coastal waters of Brazil, p. 241-250. In: PERrIN W, DonOVAN GP, BARLOW J (Ed.) International Whaling Commission: Gillnets and Cetaceans. Cambridge, Black Bear, 629p.

SIMÕEs-LoPEs PC (1988) Ocorrência de uma população de Sotalia fluviatilis Gervais, 1853, (Cetacea, Delphinidae) no limite sul de sua distribuição, Santa Catarina, Brasil. Biotemas 1: 57-56.

Simões-Lopes PC, Ximenez A (1989) Phocoena spinipinnis Burmeister, 1865, na costa sul do Brasil (Cetacea, Phocoenidae). Biotemas 3: 83-88.

Simões-Lopes PC, Ximenez A (1993) Annotaded list of the cetacens of Santa Catarina coastal waters, southen Brazil. Biotemas 6: 67-92.

Simões-Lopes PC, Drehmer CJ, Ott PH (1995) Notas sobre os Otariidae e Phocidae (Mammalia, Carnivora) da costa norte do Rio Grande do Sul e Santa Catarina - Brasil. Biociências 3: 173-181.

Van Waerebeek K, Baker AN, Felix F, Gedamke J, Iniguez M, Sanino GP, Secchi E, Sutaria D, Van Helden A, Wang Y (2007) Vessel collisions with small cetaceans worldwide and with large whales in the Southern Hemisphere, an initial assessment. The Latin American Journal of Aquatic Mammals 6: 43-69. doi: 10.5597/lajam00109

Wedekin LL, Daura-Jorge FG, Piacentini VQ, Simões-Lopes PC (2007) Seasonal variations in spatial usage by the estuarine dolphin, Sotalia guianensis (van Bénéden, 1864) (Cetacea; Delphinidae) at its southern limit of distribution. Brazilian Journal of Biology 67: 1-8. doi: 10.1590/S1519-69842007000100002

Wedekin LL, Daura-Jorge FG, Rossi-Santos MR, Simões-Lopes PC (2008). Notas sobre a distribuição, tamanho de grupo e comportamento do golfinho Tursiops truncatus (Cetacea: Delphinidae) na Ilha de Santa Catarina, sul do Brasil. Biota Neotropica 8: 225-229. doi: 10.1590/S1676-06032008000400023

Wedekin LL, Daura-Jorge FG, Simões-Lopes PC (2010). Habitat preferences of guiana dolphins, Sotalia guianensis (Cetacea: Delphinidae), in Norte bay, southern Brazil. Journal of the Marine Biological Association of the United Kingdom 90: 1561-1570. doi: 10.1017/S0025315410001414

Submitted: 13 May 2016

Received in revised form: 14 June 2016

Accepted: 5 July 2016

Editorial responsibility: Paulo da Cunha Lana

Author Contributions: Conceived and designed the study: TSV CL PCSL. Analyzed the data: TSV. Contributed with data/ materials/analysis tools: PVC MCG MJC PCSL. Wrote the paper: TSV CL PVC MCG MJC PCSL.

Competing Interests: The authors have declared that no competing interests exist. 